Spotlight on China 


\section{SPOTLIGHT ON CHINA}

Volume 1

Series Editors:

Shibao Guo, University of Calgary, Canada

Yan Guo, University of Calgary, Canada

\section{International Advisory Board:}

Yanjie Bian, University of Minnesota, USA

Qing Gu, University of Nottingham, UK

Ruth Hayhoe, OISE/University of Toronto, Canada

Khun Eng Kuah-Pearce, Monash University Malaysia, Malaysia

Baocun Liu, Beijing Normal University, China

Allan Luke, Queensland University of Technology, Australia

Gerard A. Postiglione, University of Hong Kong, Hong Kong

Barbara Schulte, Lund University, Sweden

Rui Yang, University of Hong Kong, Hong Kong

Qiang Zha, York University, Canada

Jijiao Zhang, Chinese Academy of Social Sciences, China

Li Zong, University of Saskatchewan, Canada

\section{Scope:}

Over the past decades China has experienced unprecedented economic liberalization, industrialization, mass migration, urbanization, and privatization, which have contributed to the rise of China as an emerging economic superpower. At the same time, China is also facing unprecedented challenges, including rising unemployment, socio-economic disparity, corruption, and environment degradation. Spotlight on China aims to bring together international scholars with contributions from new and established scholars to explore the profound social and economic transformation that has resulted from the market economy and its concomitant impact on education and society in China. The series includes authored and edited collections offering multidisciplinary perspectives and most contemporary and comprehensive analyses of recent social and educational changes in China.

\section{Contact Information:}

Shibao Guo, PhD

Werklund School of Education

University of Calgary

2500 University Dr. NW

Calgary, AB

T2N 1N4 Canada

Phone: 403-220-8275

Email: guos@ucalgary.ca 


\section{Spotlight on China}

Changes in Education under China's Market Economy

Edited by

Shibao Guo and Yan Guo

University of Calgary, Canada

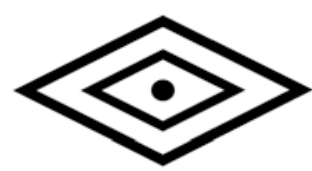

SENSE PUBLISHERS

ROTTERDAM/BOSTON/TAIPEI 
A C.I.P. record for this book is available from the Library of Congress.

ISBN: 978-94-6209-879-4 (paperback)

ISBN: 978-94-6209-880-0 (hardback)

ISBN: 978-94-6209-881-7 (e-book)

Published by: Sense Publishers,

P.O. Box 21858,

3001 AW Rotterdam,

The Netherlands

https://www.sensepublishers.com/

Printed on acid-free paper

All Rights Reserved (C 2016 Sense Publishers

No part of this work may be reproduced, stored in a retrieval system, or transmitted in any form or by any means, electronic, mechanical, photocopying, microfilming, recording or otherwise, without written permission from the Publisher, with the exception of any material supplied specifically for the purpose of being entered and executed on a computer system, for exclusive use by the purchaser of the work. 


\section{TABLE OF CONTENTS}

Foreword $\quad$ ix

Gerard A. Postiglione

1. Changes in Education under China's Market Economy: An Introduction 1 Shibao Guo and Yan Guo

Section I: Market Economy and Curriculum Reform

2. Neo-Liberal Education Policy in China: Issues and Challenges in Curriculum Reform

Charlene Tan and Vicente Reyes

3. Social Change, Citizenship, and Citizenship Education in China Since the Late 1970s

Wing-Wah Law

4. English as a Foreign Language Curriculum Reform in China: A Study in Reconstructionism Margaret Zeegers and Xiaohong Zhang

5. Ambivalent "Quality" and the Educational Sublime: Curriculum Reform Meets Ethnic Rural Development in Southwest China Jinting Wu

6. Shadow Education: The Rise and Implications of Private Supplementary Tutoring Wei Zhang and Mark Bray

\section{Section II: Teaching under China's Market Economy}

7. Teaching under China's Market Economy: The Experience of Migrant Teachers Shibao Guo

8. The Impact of the Market Economy on English Teachers Yan Guo

9. Overworked and Stressed Teachers under the Market Economy: Case Study in Northwest China Gulbahar Beckett and Juanjuan Zhao 
TABLE OF CONTENTS

10. Private Tutoring Cum Boarding Agencies and the Controlled Decentralization of China's Education System

Ying Wang and Raymond K. H. Chan

\section{Section III: Changes in Higher Education}

11. Chinese Higher Education Since 1977: Possibilities, Challenges and Tensions

Lei Zhang, Ruyue Dai and Kai Yu

12. Institutional Transformation and Aggregate Expansion of Chinese Higher Education System

Fengqiao Yan, Dan Mao and Qiang Zha

13. Massification of Chinese Higher Education: Opportunities and Challenges in a Globalizing Context Hongxia Shan and Shibao Guo

14. What Does Innovation Mean and Why Does It Matter? Innovation in Chinese Higher Education in a Global Era Heidi Ross and Yimin Wang

\section{Section IV: Transitions from Education to Work}

15. Education and Career Mobility under China's Market Economy: A Pre- and Post-Reform Comparative Analysis

Jianghua Yang, Cheng Cheng and Yanjie Bian

16. Social Inequality in Postgraduate Transition: A Case Study of University Students in Western China

Yixi Lu and Li Zong

17. Transitions from Education to Work: Dilemmas and Challenges of Graduate Un/employment

Limin Bai

\section{Section V: Market Economy and Social Inequality}

18. Inequalities in China's Compulsory Education: Progress, Inadequacies, and Recommendations

Hillary Parkhouse and Xue Lan Rong

19. Widening Urban Rural Divides: Examining Social Exclusion and Education Inequality in Chinese Schools Li Wang 
TABLE OF CONTENTS

20. Navigating the Aspirational City: Processes of Accumulation in China's Socialist Market Economy

Lorin Yochim

21. Educating Migrant Children: The Effects of Rural-Urban Migration on Access to Primary Education Charlotte Goodburn

Postscript: Policy, Markets and the Local Allan Luke

Notes on Contributors

Index

393 



\section{GERARD A. POSTIGLIONE}

\section{FOREWORD}

Massive changes continue to take place in China, as challenges abound for state and society. The country bears little resemblance to what I saw 35 years ago as I arrive at the beginning of the reform era. China of the $21^{\text {st }}$ Century is a nation of economic power, urban wealth, increasing technological prowess, and a rising international status. Nevertheless, it is still a middle-income country with its sights set on joining the league of developed economies. Its challenges include growing inequality and weak legal protections. Industries need upgrading and farmers need better access to financial services. Energy efficiency is needed to offset over-reliance on fossil fuels, while water security and food safety are urgent needs. If left unaddressed, these can derail gains of the last 35 years. Not surprisingly, education has moved to center stage in the national discourse as the means to meet the challenges, transform the economy, stabilize the society, and project soft power internationally.

The education system is distinguished by almost full-access to nine-years of basic education, with senior secondary education nearly universal in urban schools. Students in Shanghai scored above their counterparts in 60 countries on science and mathematics achievement. Colleges and universities, some approaching world-class status, are educating more students than any other country in the world. Yet, quality assurance measures point to the need to improve learning environments. The rapid expansion of the education system has produced misalignments between schools and universities, and between university graduates and the changing workplace.

China is having higher enrollment rates in tertiary education than European countries did a few decades ago. Chinese students at domestic and international universities have created what Vogel (2003) refers to as "an intellectual vitality that may be as broad and deep as the Western Renaissance." Yet, Chinese scholars including Cheung (2012) and other scholars question whether China will be "just producing more of the same of the Western-originated contemporary higher education model, or will it be able to unleash a more critical understanding and practice of higher education, a cultural and epistemological reflection of the role of universities as venues of higher learning?"

Economic globalization has made education become an instrument of international competition, as well as an instrument of international cooperation. Since the 2003 Law on Sino-foreign cooperation in the running of educational institutions, hundreds upon hundreds of jointly run Sino-foreign educational programs at schools, colleges and universities have been established on Chinese soil. As the number has increased, so has the concern about their effect on national education sovereignty. 
FOREWORD

While China tries to go global, its managing of domestic demands has become more difficult and complex. Rural households pay more and more for an education and demand that it leads to a good job for their children. Employers' dissatisfaction is manifest in their demand that graduates have relevant knowledge and skills for supporting industrial upgrading. An increasingly influential urban middle class demands that education bring with it a cultural capital and social status that advantages their children. This has fueled shadow education and opportunities to study abroad as early as junior secondary school. Meanwhile, rural migrant children struggle to obtain meaningful access to urban schools. Many get left behind in rural areas to be cared for by grandparents and supplementary school services. Finally, the state continues to demand that education be an engine for economic development but also an instrument to prepare leaders, integrate ethnic minorities, promote ideological socialization, and maintain social stability.

Such a market of multiple demands is recalibrated year by year according to how much the economy grows, how much social dissatisfaction arises, and how quickly the urban middle class prospers. If there is a unifying consensus across society, it is for education to transform China from a middle- to high- income market economy. For this to happen, there has to be a strengthened legal system to temper market forces that obstruct equity and social justice in education.

If the debates in education are any indication of what is to come, China is going to be a very different place by 2020 than what it is today, and the education system will have to work hard to keep up with social change. That is why this book by Guo and Guo makes an important contribution. The chapters systematically examine the multiplicity of intended and unintended consequences of market forces in different parts of the education system. The book moves social science research on China's education another step forward by refining the balance between the viability of mainstream western concepts and the analytical possibilities of creating a new scholarship based on a deeper understanding of the historically grounded realities of contemporary Chinese education. Such a framework requires the framing of educational issues in a balanced manner. Some contend that the study of education in China has become more and more about less and less, with microscopic level studies that tell us much about the trees and less about the forest. Yet, past studies of the education forest have often been inaccurate due to projections based on western concepts and limited empirical research. This was unavoidable when access to data on the results of educational reform and development were limited. This volume points to the possibilities of more sophisticated analysis with a growing wealth of data on Chinese education. As this continues, fresh theories of the processes of social and cultural change come to the fore. The next decade may very well become a new age of enlightenment in the study of education in China. 
FOREWORD

\section{REFERENCES}

Cheung, B. L. (2012). Higher education in Asia: Challenges from and contributions to globalization. International Journal of Chinese Education, 1(2), 177-195.

Vogel, E. (2003, December 5). China’s Intellectual Renaissance. Washington Post. 